\title{
FUNGSI DEWAN PERWAKILAN RAKYAT KABUPATEN (DPRK) DALAM PENGAWASAN KEBIJAKAN KABUPATEN ACEH BARAT
}

\author{
Salma, Cut Asmaul Husna \\ Universitas Teuku Umar \\ Email,Salmams492@gmail.com dan cutasmaulhusna@utu.ac.id
}

\begin{abstract}
Abstrak
Dewan Perwakilan Rakyat Kabupaten (DPRK) merupakan lembaga perwakilan rakyat di daerah dan berkedudukan sebagai unsur penyelenggaraan pemerintahan daerah. Oleh karena itu kebijakan daerah dan juga melakukan fungsi pengawasan oleh karena itu penelitian ini bertujuan untuk mengetahui bagaimana fungsi DPRK dalam melakukan pengawasan terhadap kebijakan daerah dan juga menganalisis berbagai faktor yang dapat mempengaruhi keberhasilan DPRK menjalankan fungsi-fungsinya dalam menjalankan pengawasan terhadap kebijakan daerah. Penelitian ini dilakukan di kabupaten Aceh Barat pada bulan juni-juli. Metode penelitian yang digunakan pada penelitian ini adalah kualitatif deskriptif. Teknik pengumpulan data diperoleh melalui dokumentasi serta wawancara langsung kepada narasumber. Narasumber pada penelitian ini berjumlah 6 orang yang dipilih melalui teknik purposive sampling. Adapun hasil penelitian ini menunjukkan bahwa fungsi DPRK pada proses pengawasan kebijakan daerah melalui proses diantaranya yaitu penyusunan Anggaran, fungsi Anggaran Pendapatan dan Belanja Kabupaten (APBK), pelaksanaan kebijakan daerah, dan pertanggung jawaban terhadap kebijakan daerah oleh eksekutif. Hasil penelitian ini juga menunjukkan bahwa faktor-faktor lain yang dapat mempengaruhi pelaksanaan fungsi DPRK dalam melakukan pengawasan kebijakan daerah yaitu kompetensi anggota DPRK, ketersediaan sarana dan prasarana, serta ketepatan waktu dalam melakukan pengawasan.
\end{abstract}

Kata kunci: Fungsi; Pengawasan; Kebijakan.

\section{Abstract}

This study aims to find out how the DPRK functions in supervising regional policies and also to analyze various factors that can affect the success of the DPRK in carrying out its functions in carrying out supervision of regional policies in West Aceh Regency. This research method is descriptive qualitative. The results of this study indicate that the function of the DPRK in the process of supervising regional policies, through processes including the preparation of the budget, the function of the budget, Regency Revenues and Expenditures $(A P B K)$, implementation of regional policies, and accountability for regional policies by the executive. The results of this study also indicate that other factors that can affect the implementation of the DPRK's function in supervising 
regional policies are the competence of DPRK members, the availability of facilities and infrastructure, and the timeliness of supervising.

Keywords: Function; Supervision; Policy.

Diterima: 25-10-2021Ｄirevisi: 14-12-2021_ Diterbitkan: 20-12-2021

\section{Pendahuluan}

Berdasarkan Pasal 17 Undang-Undang Nomor 11 Tahun 2006 tentang Pemerintahan Aceh, Pemerintah daerah kabupaten berwenang melakukan urusan wajib guna memberikan pelayanan yang optimal kepada warga masyarakat di tingkatan Kabupaten/Kota. Tetapi, tidak seluruh kewenangan tersebut dapat terlaksana sebagaimana mestinya. Oleh sebab itu, dibutuhkan adanya pengawasan baik yang dilakukan oleh lembaga legislatif ataupun pengawasan yang dilakukan oleh pemerintah pusat (Al-Faraji, 2006)

Pemerintahan Daerah yang baik ialah isu yang sangat mengemukakan dalam pengelolaan administrasi publik. Pemerintahan tuntutan oleh masyarakat terhadap penyelenggaraan pemerintahan daerah yang baik serta implementasi yang baik yang sejalan terhadap meningkatnya pengetahuan masyarakat (Amrizal, Husni A. Jalil, 2013). Di samping itu, juga adanya pemerintahan dari rulling government yang terus bergerak yang beralih dari paradigma dengan mengarah kepada good governance sebagai kejadian berdemokrasi secara adil. Dalam hal ini dibutuhkan fungsi dari Dewan Perwakilan Rakyat Kabupaten (DPRK) yang kokoh, berkarakter, dan beraspiratif.

Dewan Perwakilan Rakyat Kabupaten (DPRK) yang berperan menjadi wakil rakyat, hendaknya senantiasa memperjuangkan serta mencermati apa yang menjadi aspirasi rakyat, yang sesuai dengan tugas pokoknya serta fungsinya. Salah satu adalah otonomi daerah. Otonomi merupakan hak, kewenangan dan tugas pemerintah daerah untuk mengelola dan mengatur daerahnya berdasarkan peraturan dan perundangundangan yang diberlakukan. Berdasarkan konteks penerapan otonomi daerah, para pemimpin daerah harus bersikap netral dalam melakukan berbagai kebijakan dan tidak berorientasi untuk mendapatkan kewenangan yang sebesar-besarnya dan mengenyampingkan tujuan dari otonomi yang diberikan. Dimana otonomi merupakan suatu kebutuhan atas efesiensi serta efektifitas manajemen penyelenggaraan pemerintah yang bertujuan membagikan pelayanan kepada mayarakat (Fauzi, 2014)

Selaku lembaga perwakilan di Kabupaten, DPRK memiliki fungsi yang kuat dalam memberikan warna terhadap jalannya suatu pemerintah daerah otonom. Uraian ini menunjukkan bahwa pandangan lembaga legislatif penting untuk terus mengembangkan dirinya, serta tidak jauh dari dinamika mutu prasarana publik, memiliki ikatan dengan lembaga yang lain dalam lingkup norma-norma pemerintahan. DPRK memiliki tiga(3) fungsi utama dalam lembaga legislatif yaitu: 1) fungsi pengawasan, 2) fungsi Legislatif, dan 3) fungsi Anggaran (Asiri, 2019). 
DPRK memiliki fungsi pelaksanaan pengawasan terhadap beragam kebijakan publik dalam daerah yang dilakukan oleh lembaga eksekutif yang di dalamnya terdapat pengawasan terhadap kebijakan pelaksanaan APBK. (Amrizal, Husni A. Jalil, 2013)

Pengawasan ialah fungsi akhir dari seseorang pemimpin sesudah melaksanakan berbagai fungsi sebagai leader yang lain yaitu (perencanaan, pengorganisasi, serta pengandalian). Pengertian pengawasan menurut George $R$ Terry merupakan suatu kegiatan atau tahapan untuk menentukan apakah pekerjaan yang telah diimplementaikan sudah dilakukan dengan sesuai dengan rencana, dan melakukan penilaians serta koreksi jika diperlukan dengan maksud agar hasil kerja sesuai dengan rencana semula(Fauzi, 2014)

Pengawasan adalah proses yang dilakukan secara berkesinambungan yang dilakukan secara seksama dan dalam waktu yang reguler/periodik. Untuk melakukan pengawasan diperlukan kerjasama antara berbagai pihak terkait dan rasa saling percaya. Tujuan akan tercapai jika pelaksanaan rencana berjalan sesuai waktu, dan anggaran yang sudah ditetapkan, dan dilakukan perbaikan yang diperlukan dengan sesegera mungkin agar tidak terjadi kesalahan yang terus-menerus (Junfahrizal, Ramadhani Setiawan, 1967)

Pengawasan diperlukan oleh berbagai pihak pemerintah, aparat pemerintah daerah dan juga pusat. Pada pokoknya pengawasan dilaukan agar tidak terjadi tindakan yagn dapat merugikan kepentingan umum dan untuk mencegah dampak yang signifikan jika hal itu terjadi (Musliadi SH)

Dewan Perwakilan Rakyat Kabupaten (DPRK) merupakan lembaga perwakilan rakyat di daerah dan berkedudukan sebagai unsur penyelenggaraan pemerintahan daerah. Oleh karena itu kebijakan daerah dan juga melakukan fungsi pengawasan (Karim, 2011).

Fungsi pengawasan ini berarti DPRK agar lebih kreatif serta aktif menghadapi berabgai hambatan terhadap implementasi perda. Dengan pengawasan oleh DPRK, eksekutif selaku pelaksana kebijakan akan terhindar dari bermacam penyalahgunaan dan penyelewenagnan. Pengawasan dan hasil yang dilakukan DPRK akan diambil aksi pembenaran dalam perbaikanimplemantasi kebijakan. Pengawasan DPRK sangatlah penting terhadap daerah karena para angota DPRK ialah yang mengurus dalam daerah demi melaksanakan qanun yang telah ditetapkan oleh pemerintah baik berkaintan dengan Anggaran,APBN,APBK, dalam daearah dan kebijakan lainnya yang sunguhsunguh harus dengan adanya pengawasan dari DPRK.

Disini peneliti melihat pelaksanaan tugas dan fungsi DPRK Kabupaten Aceh Barat sebagai lembaga legislatif daerah berhubungan secara khusus dengan fungsi pengawasan badan eksekutif. Menurut peneliti kebijakan pengawasan yang saat ini dijalankan ada belum optimal, masih ditemukannya bangunan yang sudah dibangun namun tidak digunakan secara bagaimana keperluan semestinya, seperti pada pembangunan gedung-gedung sekolah di daerah terpencil. Selain itu kasus lain misalnya di daerah yang terpencil membutuhkan seorang guru yang berprofesi dalam bidang tertentu misalkan seorang Guru Bahasa Inggris, namun tidak diperhatikan sesuai 
kebutuhan. Kemudian ada juga ditemukan persoalan tentang tidak sesuai penggunaaan anggaran dengan alokasi anggaran yang tercantum dalam dokumen yang telah disusun, padahal di sisi yang lain Para Anggota Dewan telah turun langsung ke lapangan untuk melihat keadaannya dan kerja sama dengan Inspektorat untuk menjalankan pengawasan kebijakan yang telah dibentuk. Sebagaimana disampaikan saat rapat di DPRK Aceh Barat

Sebagai sebuah lembaga politik Dewan Perwakilam Rakyat Kabupaten (DPRK) yang di bentuk di setiap propinsi dan kabupaten/kota pada umumnya dipahami sebagai lembaga yang menjalankan kekuasaan legislative yang memilih peran penting dalam melaksanakan pengawasan terhadap persoalan yang terjadi dalam upaya peningkatan pelayanan publik dan eksekutif dalam menjalankan dan melaksanakan pembangunan sesuai dengan perencanaan dan kebijakan.

Di Aceh, pelaksanaan kebijakan otonomi daerah terus berlanjut dengan dibuatnya Undang-Undang Nomor 11 Tahun 2006 tentang Pemerintahan Aceh (selanjutnya disebut dengan UUPA yang mengatur penyelenggaraan pemerintah otonomi untuk Aceh serta memiliki kewenangan untuk kesejahteraan masyarakat Aceh yang seluas-luasnya. Pemerintah Daerah dan Dewan Perwakilan Rakyat Kabupaten (DPRK) merupakan institusi yang memiliki kewenangan dalam melakukan tata kelola pemerintahan yang baik dan merupakan institusi vital di Aceh (Trisna \& Marefanda, 2018).

Kebijakan merupakan serangkaian asas-asas dan konsep yang digunakan sebagai panduan dan landasarn dalam merencanakan suatu tugas atau tanggung jawab kerja, tindakan dan kepemimpinan. Kebijakan dapat diterapkan untuk berbagai tingkatan organisasi, pemerintahan, perusahaan dan kelompok-kelompok.

Fungsi kebijakan adalah menajamin ketertiban dalam negara atau dalam daerah sesuai dengan ditingkat mana kebijakan itu dibuat. Adapun tujuan kebijakan nya ialah untuk mengatur kehidupan penduduk wilayah tentu agar tercipta ketertiban, kenyamanan, dan keaman.

Berdasarkan uraian latar belakang diatas, fokus penelitian ini adalah bagaimana fungsi Dewan Perwakilan Rakyat Kabupaten (DPRK) dalam melakukan pengawasan terhadap kebijakan daerah melalui studi kasus pada kantor DPRK Kabupaten Aceh Barat.

\section{Metode Penelitian}

Adapun metode penelitian yang diterapkan dalam penelitian ini adalah pendekatan kualitatif. Metode ini digunakan untuk mengungkapkan berbagai fenomena secara holistik kontekstual, dengan data yang sudah dikumpulkan dari lapangan secara natural dimana peneliti berfungsi sebagai instrumen kunci. Terkait dengan penelitian ini peneliti mencari data selengkap mungkin yang berkaitan dengan fungsi dan tanggung jawab DPRK dalam mengawasi pelaksanaan kebijakan daerah di Aceh. Peneliti menggunakan teknik pengumpulan data dengan data primer dan sekunder yaitu data dari beberapa pihak yang ada di DPRK yang dianggap memiliki kompetensi dalam 
menjawab pertanyaan dan rumusan masalah penelitian. Untuk data sekunder peneliti menggunakan berbagai jurnal, literatur, textbook dan referensi terkait untuk landasan teori dan memperoleh hasil penelitian.

\section{Hasil dan Pembahasan}

\section{Pengawasan Pelaksanaan Kebijakan Daerah}

Fungsi pengawasan ada banyak diantaranya yaitu memudahkan pihak manajemen organisasi untuk melaksanakan tanggung jawabnya dengan melakukan analisis, evaluasi, rekomendasi dan menyampaikan laporan hasil kerja secara efektif dan efesien. Pengawasan pada prinsipnya dilakukan oleh pihak DPRK dibantu oleh beberapa pihak lainnya hingga semuanya terjalankan sesuai dengan tujuan atau sasaran direncanakan atau ditetapkan. Adapun yang diawasi dalam hal anggaran adalah semua anggaran yang digunakan oleh pihak yang mendapatkan dana. Secara ringkas, pengawasan anggaran adalah mengawasi kongruensi antara anggaran yang diminta, disetujui dan digunakan pada realisasi anggaran misalnya pembuatan gedung, pembelian sarana dan prasarana, pembangunan jalan dan lainnya. Pengawasan anggaran mengharuskan adanya prinsipprinsip transparansi, akuntabilitas dan aksesibilitas yang sangat baik. Hal ini berlaku untuk semua pihak yang terlibat dan bertanggung jawab untuk pengawasan yang dilakukan yaitu DPRK dan juga anggota masyarakat dalam masa satu tahun angggaran.

Di dalam (Peraturan Dewan Perwakilan Rakyat Kabupaten Aceh Barat Nomor 1 Tahun 2021 Tentang Tata Tertib Dewan Perwakilan Rakyat Kabupaten Aceh Barat, 2021) Pasal 139 ayat 1 menyatakan bahwa "Setiap Komisi menyusun agenda pengawasan dalam 1 (satu) tahun sidang pada permulaan tahun anggaran berkenaan untuk jangka waktu paling lama 7 (Tujuh) hari. Penyusunan Agenda pengawasan sebagaimana dimaksud pada ayat (1) disesuaikan dengan bidang tugas masing-masing Komisi dan didasarkan atas hasil penilian dan evakuasi LKPJ tahun sebelumnya." Agenda pengawasan Komisi setidaknya harus memuat penetuan atas: a). Objek Pengawasan b). Waktu Pengawasan c). Anggota DPRK dan para pihak yang terlibat dalam pengawasan.

Menurut hasil wawancara di lapangan diperoleh bahwa Dewan Perwakilan Rakyat Kabupaten (DPRK) Aceh Barat turut pula melakukan fungsi pengawasan. Terkait hal ini DPRK Aceh Barat selaku lembaga legislatif melaksanakan kegiatan pengawasan sebagai berikut:

1. Melaksanakan pengawasan untuk semua kegiatan yang berkaitan dengan proyek pemerintah, baik pemerintah daerah dan kabupaten yang mencakup bidang daerah yang seperti pemerintah, pembina sosial politik, sektor sosial dan ekonomi.

2. Memeriksa kebenaran tentang suatu laporan kemungkinan adanya penyalahgunaan atau penyelewenangan terkait kegiatan pemerintahan, aspek social ekonomi, politik, aparat negara, APBD dari masyrakat.

3. Mengusut laporan yang disampaikan oleh masyarakat terkait keterlambatan, penyimpangan, penyalahgunaan tugas-tugas aparatur di lingkup Pemkab Aceh Barat dan dalam lingkungan DPRK Aceh barat itu sendiri. 
4. Melakukan evaluasi dan melaporkan pelaksanaan tugas dan fungsi Pemkab Aceh Barat (Laporan Keuangan DPRK Aceh Barat).

Para Dewan pernah menelusuri langsung kelapangan keterkaitan dengan APBK tahun 2020 terhadap SKPK. Apakah berjalan dengan baik atau tidak ? namun pada rapat hari selasa tanggal 26 juni 2021 adanya pendapat dari dewan bahwa setelah melihat langsung ke lapangan banyak sekali bangunan yamng di bangun namun tidak berfungsi atau digunakan. Di daerah yang terpencil lebih membutuhkan seorang pengajar dibandingkan bangunan yang tidak dimanfaatkan sebagaimana selayaknya digunakan. Hal ini sangat menjadi perhatian untuk masyarakat yang berada di daerah terpencil. Para anggota Dewan telah melakukan musyawarah bersama dengan kerabat kerja seperti Inspektorat mengenai bagaimana keputusan terhadap pengajar untuk di daerah Terpencil yang sangat-sangat membutuhkan seorang pengajar (Musliadi SH).

\section{Menentukan Agenda Pengawasan}

Perencanaan yang detail dan seksama merupakan awal dari keberhasilan aparat pemerintah dalam melaksanakan tugas dan tanggung jawabnya. Maka dari itu penyusunan rencana kegiatan Pengawasan DPRK merupakan salah satu unsur penting dalam menentukan efektifitas pengawasan yang akan diproses. Langkah kemudian menentukan teknik pengawasan yang hendaknya dimulai dengan mendapatkan dan mencari informasi awal yang lengkap dan diakhiri dengan menyusun rekomendasi atas hasil analisis. (Anam \& Anwar, 2020)

\section{Penyusunan Anggaran Pendapatan Belanja (APBK)}

Setiap tahunnya berkaitan dengan metode penyusunan anggaran DPRK ada penerapan mekanisme khusus dimana administratif Sekretaris DPRK bertanggung jawab kepada Bupati melalui Sekretaris Daerah, dengan demikian rencana anggaran DPRK akan dimasukkan kedalam buku RAPBK untuk disampaikan kepada DPRK agar dibahas dan dapat disetujui bersama-sama. (Nila Trisna, Husni Jalil, 2015)

\section{Tahap yang dilakukan dalam penyusunan:}

a) Di awali exsekutif melalui musrembang dari desa sampek ke kabupaten dengan melibatkan semua komponen masyarakat. Pada saat musyawarah

b) Pemerintah menyusun RKPD

c) Ajukan anggaran di program kegiatan yang lakukan tahun depan melalui KUA-PPAS ke DPRK

d) SKPD menyusun perencanaan kerja anggaran

e) Menjadi SKPK setelah melakukan membahas dengan DPRK.

Program dalam menentukan pembangunan satu tahun ialah Para DPRK dan kesekretariat memiliki hak dan tanggung jawab untuk program pembangunan. Para anggota mengusulkannya melalui Pokir hal ini didapakat melalui aspirasi anggota dewan saat melakukan reses yang diawali dengan program pelayanan dalam rangka memfasilitasi Tupoksi Dewan. 
Penyusunan APBD Pemkab Aceh Barat dimulai dengan menentukan batas anggaran APBK sesuai siklus anggaran dimulai: 1) tahap menentukan penerimaan daerah, 2) tahap menentukan belanja rutin, dan 3) tahap menentukan belanja pembangunan atau belanja modal. Setelah diperoleh hasil rencana anggaran maka selanjutnya disampaikan kepada kepala Daerah untuk ditinjau kemudian RAPBK tersebut dilaporkan kepada DPRK untuk bersama-sama dibahas dengan badan eksekutif (SKPK terkait). Para pihak legislatif diharapkan dapat memberikan masukan, gagasan ataupun usulan kepada badan eksekutif dengan anggaran pembangunan tahunan dan kebijakan anggaran tahunan yang telah disetuju sebelumnya ketika membahas RAPBK tersebut.

Pada tahapan ini DPRK bertugas untuk mengumpulkan dan memberikan aspirasi kepada rakyat. Menyampaikan arahan atau informasi mengenai APBK dan juga menetapkan metode dan prioritas dari APBK, juga mendiskusikan tentang APBK dalam rapat paripurna. DPRK juga bertugas untuk membuat keputusan secara kolektif kolegial. Secara ringkas, pengawasan anggaran adalah mengawasi kongruensi antara anggaran yang diminta, disetujui dan digunakan pada realisasi anggaran misalnya pembuatan gedung, pembelian sarana dan prasarana, pembangunan jalan dan lainnya. Pengawasan anggaran mengharuskan adanya prinsip-prinsip transparansi, akuntabilitas dan aksesibilitas yang sangat baik. Hal ini berlaku untuk semua pihak yang terlibat dan bertanggung jawab untuk pengawasan yang dilakukan yaitu DPRK dan juga anggota masyarakat dalam masa satu tahun angggaran

\section{Pertanggung Jawaban Pengawasan Kebijakan Daerah Kabupaten}

Salah satu tokoh masyarakat kabupaten Aceh Barat menjelakan tentang kinerja anggota DPRK bahwa "selama ini yang dilakukan oleh anggota DPRK tentang pertanggung jawaban dewan baik mengenai anggaran dan lain sebagainya. Kita sebagai masyarakat tidak mengetahui hal mengenai baik masalah anggaran dan ketetapan lainnya karena para masyarakat tidak pernah diundang jika ada pembahasan mengenai hal tersebut. Beliau mengatakan karna hal itu pula kami menjadi apatis akan hal tersebut.

Pengertian istilah pengawasan berasal dari kata awas, berarti antara lain "penjagaan". Pengawasan merupakan salah satu tugas dalam manajemen dan juga administrasi yang berkaitan dengan pengelolaan (Fachrudin, 2004: 88). Muchsan dalam Irfan Fachrudin (2004: 89), menjelaskan bahwa pengawasan merupakan tindakan untuk mengukur dan memberikan penilaian pada implementasi tugas dan tanggung jawab yang diberikan sebagai penentu, sementara pengawasan bertujuan untuk menyesuaikan apakah implementasi sudah dilakukan dengan benar sesuai dengan rencana yang ditentukan sebelumnya berikut dengan tolak ukur keberhasilannya.

Pengawasan mempunyai prinsip yaitu dilakukan secara berkelanjutan dan dengan seksama. Untuk melakukan pengawasan diperlukan kerjasama antara berbagai pihak terkait dan rasa saling percaya. Tujuan akan tercapai jika pelaksanaan rencana berjalan sesuai waktu, dan anggaran yang sudah ditetapkan, dan dilakukan perbaikan yang diperlukan dengan sesegera mungkin agar tidak terjadi kesalahan yang terus-menerus. 
Didalam melaksanakan pengawasan ada pula penyampaian hasil dan sudut pandang agar penyalahgunaan atau penyelewenangan kerja maupun dana tidak terulang kembali dikemudian hari (Sunindhia, 1987: 112).

Para anggota DPRK memiliki tangung jawab yang besar dalam melakukan kebijakan yang telah di tentukan yang sesuai dengan tata-tertip yang ada untuk menjalankan tugas yang telah diberikan dan dipercayakan sebagai tempat pengaduan masyarakat daerah. Para anggota Dewan harus mampu mengayomi masyarakat dengan baik dan membuat masyarakat puas terhadap pimpinan mereka dengan tidak hanya nebebarkan janji namun juga memberikan bukti yang nyata kepada masyarakat yang telah mepercayai Daerah ini dibawah pimpinan para anggota dewan.

Pertanggungjawaban mekanisme pengawasan yang dilakukan oleh DPRK bisa dilaksanakan dengan cara sebagai berikut:

1. Pengawasan individual yang ditetapkan dengan rencana dengan pelaksanaan kegiatan reses dan anggaran yang sudah ditentukan sebelumnya sesuai standar dan pertanggungjawabannya juga sudah ada memiliki ketentuan sendiri. Setiap anggota DPRK di bebankan membuat laporan hasil pengawasan dan di sampaikan kepada pimpinan DPRK, baik lewat pesan formal yang dikirimkan untuk seluruh anggota, komisi, fraksi, termasuk sekretariat dewan serta media massa atau pun dalam persidang paripurna anggota DPRK.

2. Penangungjawaban hasil pengawasan komisi umumnya dilakukan lewat rapat teratur komisi secara internal dalam periode mingguan. Walaupun demikian secara kelembagaan bersumber pada tata tertib DPRK di agendakan rapat pleno untuk 3 bulan masa persidangan. Dalam forum ini, tiap-tiap anggota DPRK melalui persidang pleno hendak mengantarkan hasil kinerja sepanjang 3 bulan masa persidangan.

3. Perihal yang sama dengan hasil pengawasan yang dicoba dengan baik melalui gabungan komisi serta pansus. Hasil nya hendak di berikan kepada pimpinan DPRK.

4. Hasil pengawasan, baik pribadi, komisi, gabungan komisi serta pansus pula bertangung jawab lewat rapat pimpinan yang lebih kondusif.

5. Hasil pengawasan DPRK dapat dipertanggung jawabkan lewat per sidangan paripurna ataupun dengan menyertakan publik lewat forum penilaian ketika pesidangan DPRK dilakukan.

6. Selain itu DPRK perlu memperhatikan bentuk laporan informasi dari pengawasan yang telah dilakukan agar lebih mudah diketaui oleh masyarakat atau para pihak yang berkepentingan.

Juga melakukan musyawarah untuk bertukar pendapat yang terkait dengan suatu permasalahan lalu dibentuklah rapat-rapat baik dengan pendapatan kerja, kordinasi, ddl. Terhadap saat permasalahan dengan langsung kelapangan misalnya pada saat banjir Seperti PANSUS. Pada faktanya dilapangan bahwa pengawasan yang dilakukan secara perorangan lebih efektif daripada pengawasan oleh suatu kelompok komisi. Caranya 
adalah dengan terjun langsung ke lokasi atau area secara langsung masyarakat yang ada di wilayah konstituennya. Dalam hal ini anggota Seketariat memiliki hak-hak yang dibentuk oleh lembaga DPRK yaitu 1) Hak ingterpirasi (hak mendapatkan perjelasan suatu permasalahan exsekutif) 2) Hak angket (untuk melakukan penyelidikan terhadap suatu kebijakan exsekutif) 3) Hak menyatakan pendapat (wawancara 25 juli 2021).

Masa reses merupakan waktu dimana komisi bisa berkunjung langsung ke daerah pemilihannya dan mencari informasi mengenai berbagai masalah yang dihadapi mereka baik terkait dengan pembangunan, anggaran, dan lainnya yang nantinya akan dinformasikan lebih lanjut kepada pimpinan DPRK, baik melalui surat resmi yang diberikan langsung kepada fraksi dan komisi. Selain itu apabila ketika sedang mengadakan kunjungan ternyata ditemukan masalah yang harus segera ditangani saat itu itu, maka akan dilakukan rapat resmi fraksi sebagai bentuk kepedulian dan tanggung jawab kepada para pendukung mereka. Masa reses dilaksanakan paling lama 6 (enam) hari dalam 1(satu) kali reses bagi DPRK dan Sektertaris DPRK mengumumkan agenda reses setiap Anggota DPRK paling lambat 3 (tiga) Hari sebelum masas reses dimulai melalui saluran yang mudah diakses. Data didapatkan Dari (Wawancara tgl 22 juli 2021)

\section{Pengawasan Kebijakan Anggaran}

Pengawasan adalah suatu usaha yang dilakukan secara sistematis untuk menentukan standar kinerja pada suatu rencana yang dibuat dan untuk mendesain metode umpan balik informasi. Pengawasan diperlukan untuk melakukan perbandingan pada hasil pencapaian kerja yang sesungguhnya, dan mengetahui apakah ada penyimpangan yang telah terjadi dan juga untuk menentukan tindakan koreksinal yang dibutuhkan untuk memastikan bahwa seluruh sumber daya yang disediakan leh pemkab telah dimanfaatkan dengan efektif dan efesien. Pada dasarnya pengawasan dilakukan untuk mencegah terjadinya penyalahgunaan atau penyimpangan dari rencana atau tujuan yang sudah ditetapkan (wawancara 25 juli).

Pengawasan yang dilaksanakan oleh DPRK bukan sebagai suatu audit atau pemeriksaan namun pengawasan yang dimaksudkan mengetahui penggunaan dan penyusunan anggaran yang telah disediakan untuk rencana program yang sudah dibuat dan ditentukan sebelumnya, tidak boleh terjadinya menyimpang dalam pelaksanaan nya serta dapat di pertanggung jawabkan penggunaan anggaran. (S.IP., 2020)

Anggaran adalah sejumlah uang yang di habiskan dalam waktu tertentu untuk melakasanakan suatu program yang telah dibentuk dan akan dijalankan dalam jangka waktu baik bulan ataupun tahun.

a) Fungsi Anggaran

Pada pasal 17 menyebutkan Fungsi anggaran DPRK diwujudkan dalam bentuk pembahasan untuk persetujuan bersama terhadap rencana Qanun tentang APBK yang diajukan oleh Bupati. Fungsi anggaran dilaksanakan dengan cara : 1) membahas kebijakan umum APBK dan prioritas dan plafon anggaran sementara yang disusyn oleh Bupati berdasarkan rencana kerja perintah Daerah, 2) menbahas rancangan qanun tentang APBK, 3) Membahas rancangan Qanun tentang perubahan APBK, 4) 
Membahas rancangan qanun pertanggung jawaban pelaksanaan APBK.

Dalam fungsi pengawasan anggaran dewan membentuk tim khusus untuk meninjau langsung kelapangan, jika ditemukan ketidak sesuaian penggunaan anggaran yang digunakan atau program yang sudah di dirikan namun belum siap dalam waktu yang telah di tetapkan. Maka hal ini akan di lakukan pemanggilan terhadap yang melakukan pengawasan misalkan yang memangang tangung jawab terhadap program pembangunan jembatan ialah PU, kemudian member arahan kepada Konsulta dan para pekerja untuk menjalankan tugas yang telah diberikan dengan tepat pada waktunya. Jika tidak selesai pada waktu yang telah ditentukan maka akan dimintanya pertangung jawaban oleh angota DPRK ataupun Kesekretariatan untuk mencari solusi agar program yang telah ditentukan berjalan dengan baik akan selesai pada waktu yang telah di tetapkan pada masa pembentukan KUA .

Untuk melakukan pengawasan terhadap anggaran ada beberapa pihak yang mempunyai wewenang melakukan hal tersebut termasuk sekretarik DPRK, pihak Inspektorak BPK dan BPKP serta Inspektorat Kabupaten sendiri. Seluruh aktifitas pengawasan yang dilaksauakan bertujuan untuk mencegah terjadinya penyalahgunaan penggunaan anggaran dari rencana yang sudah ditetapkan sebelumnya. Pengawasan juga dilakukan untuk memastikan tidak adanya kesengajaan misalnya menggelembungkan harga material atau sumber daya yang diperluken untuk sebuah proyek atau untuk perjalanan dinas, anggaran yang dimaksud adalah anggaran yang bersifat fiktif atau semacamnya. Untuk mengatasi hal itu, ada beberapa saran yang dapat diberikan yaitu melakukan pengawasan yang lebih ketat dan menekankan kepada semua pihak penggunan anggaran agar tidak boros dan memaksimalkan pekerjaan dengan anggaran yang sudah tersedia dan menjalankan rencana untuk mencapai sasaran seoptimal mungkin.(wawancara 25 juli)

Pengawasan yang dilaksanakan oleh DPRK bukan sebagai suatu audit atau pemeriksaan namun pengawasan yang dimaksudkan mengetahui penggunaan dan penyusunan anggaran yang telah disediakan untuk rencana program yang sudah dibuat dan ditentukan sebelumnya, tidak boleh terjadinya menyimpang dalam pelaksanaannya serta dapat di pertanggung jawabkan penggunaan anggarannya. (S.IP., 2020)

b. Pelaksanaan Anggaran Daerah

Pemerintah daerah harus dapat mengenali berbagai peluang dan kesempatan yang ada pada tiap-tiap daerah dan selanjutnya dapat mengembangkan suatu program yang tepat sesuai dengan rencana dan tujuan pembangunan daerah. Pelaksanana anggaran diartikan sebagai tahapan dimana dana atau fasilitas dimanfaatkan untuk menjalankan kebijakan anggaran yang telah disusun dengan baik namun pada kenyataannya tidak dilaksanakan dengan tepat (Nila Trisna1, Husni Jalil2 , Eddy Purnama3)

\section{Faktor-Faktor yang Mempengaruhi Pelaksanaan Fungsi Pengawasan DPRK Kabupaten Aceh Barat terhadap Kebijakan Daerah.}


Dalam UU Nomor. 23 Tahun 2014 tentang pemerintah Daerah (Lembaga Negara Republik Indonesia Tahun 2014 nomor 244, tambagan lembaga Negara Republik Indonesia Nomor 5579). (Perbup Aceh Barat, n.d.).

DPRK harus sanggup mengawasi semua kebijakan dan penyelenggaraan pemda serta tata kelola Badan Usaha Milik Daerah (BUMD) serta usaha lainnya dengan baik. Kegiatan yang dilakukan merupakan dengan melaksanakan penyelidikan, pengujian, dan evaluasi atas kinerja fitur daerah serta Badan Usaha Milik Daerah (BUMD). Komisi melaksanakan pengawasan dalam tiap masa persidangan sesuai jadwal serta penjadwal yang telah ditetapkan oleh Badan Musyawarah. Ada sebagian aspek yang berpengaruh pada optimaslisasi pelaksanaan pengawasan DPRD terhadap penyelenggaraan pemda, diantaranya:

\section{a. Kualitas Anggota DPRK}

Pengawasan pemda akan dapat dilakukan dengan optimal jika didukung oleh kualitas pengawasan yang tinggi dan kompeten. Para pengawas seharusnya mempunyai kemampuan, kecakapan dan kompetensi yang memadai agar dapat melakukan fungsi dan tangguna jawabnya sebagai pengawas dengan baik serta mampu menerjemahkan ketentuan serta kebijakan dan peraturan-peraturan daerah berdasarkan rencana program yang sudah ditetapkan oleh APBK sebelumnya.

Di DPRK Aceh Barat yang saya lihat tidak semuanya melakukan kerja dengan baik menurut pengamatan langsung yang saya dapatkan.

\section{b. Dukungan Sarana dan Prasarana}

Dalam memperkuat pengawasan terhadap kebijakan pemerintah daerah, membutuhkan ketersediaan berbagai infrastruktur, sarana dan prasarana seperti bangunan perkantoran yang mendukung, kondisi yang bagus, jaringan teknologi informasi dan komputer yang cepat, tersedianya kendaraan operasional yang dapat digunakan setiap waktu dan lainnya. Salah satu hal yang dapat memperlambat kerja anggota DPRK yaitu sarana dan prasarana yang terbatas tersebut sehingga kinerja menjadi tidak optimal.

Dalam gedung perkantoran memiliki fasilitas yang memadai memenuhi kebutuhan yang dibutuhkan oleh para dewan dan juga anggota kesekretariat Aceh Barat dengan ruang yang nyaman dan melakukan kerja dengan baik sesuai jabatan yang telat dipercayai untuk melakukan pekerjaan dengan sebaik-baiknya.

\section{c. Ketepatan Waktu}

Ketepatan waktu merupakan salah satu hal yang sangat penting didalam menjalan fungsi pengawasan oleh DPRK. Jika pengawasan tidak dilakukan secara tepat waktu maka akan ada kesulitan atau kendala yang besar yang dapat dihadapi ketika mengawasi dan menilai kinerja pemerintah daerah. Ketepatan waktu juga dapat membantu pengawas mengetahui adanya kemungkinan penyalahgunaan atau pelanggaran oleh eksekutif. Perihal ini bisa jadi terhambat kerena adanya agenda lainnya yang harus di tuntaskan untuk keperluan DPRK. 
Fenomena ini sejalan dengan indikator evaluasi pelaksanaan fungsi pengawasan sebagaimana yang dijelaskan oleh Sarwoto (2010), yaitu kegiatan pengawasan akan berlaku dan mencapai hasil yang optimal jika didukung faktor-faktor seperti ketepatan waktu, obyektif, realitas, terfokus, unsur ke akuratan data dan terkoordinasi.

Dilokasi yang saya amati tentang ketepatan waktu yang saya lihat dilangsung di DPRK banyak sekali ketidak tepat waktu. Misalkan pada saat adanya Rapat dilakukan para anggota Dewan sering kali terlambat datang dari jam yang sudah ditentukan oleh pihak pelaksaan Rapat. Baik dalam Rapat Biasa ataupun Rapat Persidangan tentang penetapan perubahan Qanun.

Namun tidak hanya pada kegitan di dalam kantor saja hal ketepatan waktu juga dapat kita liat dalam program/kegitan POKIR yang sudah di atur dalam aturannya harus menjalankan tugas dengan baik dan harus selesai pada waktu yang telah ditentukan. Pokir adalah usulan-usulan dari masyarakat/kelompok yang ditampung pada saat anggota DPRK melakukan kegiatan Reses.

\section{d. Anggaran}

Merupakan salah satu faktor yang dapat meperlambat kerja para anggota Dewan dan juga para PNS yang membantu kinerja para pimpinan. Terkadang anggaran tidak cukup dalam bentuk SPPD maka akan menghambat kerja dalam hal pengawasan dewan untuk turun langsung ke lapangan.

\section{Kesimpulan}

Didalam pengimplementasian peranan pengawasan kebijakan daerah ada pedoman tertentu yang dijadikan sebagai dasar untuk pelaksanaan oleh DPRK Kabupaten Aceh Barat. Hal ini bertujuan untuk mewujudkan sistem pengawasan yang tepat, objektif, pasti, dan akuntantabel. Metode yang digunakan oleh DPRK Aceh Barat termasuk menyusun fungsi Anggaran Pendapatan dan Belanja Daerah yang dikontrol secara seksama melalui laporan pelaksanaan, rapat-rapat dengar pendapat, fraksi, rapat komisi, dan juga pengendalian ketika diminta mempertanggungjawabkan laporan oleh pemda pada saat sidang paripurna dilaksanakan.

Berdasarkan hasil penelitian ini dapat diketahui adanya beberapa faktor yang memberikan pengaruh terhadap fungsi pengawasan DPRK terhadap pencapaian kerja pemda yang termasuk kecakapan dan kemampuan secara individual masing-masing anggota DPRK terkait pemahaman dan pelaksanaan semua aturan dan kebijakan yang disediakan, juga memahami sarana dan prasarana serta fasilitas kantor yang cukup dan waktu yang tepat untuk memeriksa dan menguji kemungkinan terjadinya pelanggaran oleh badan eksekutif. 


\section{BIBLIOGRAFI}

Al-Faraji, Hadi Ahmed. (2006). Undang Undang Republik Indonesia Nomor 11 Tahun 2006 Tentang Pemerintahan Aceh. Vascular Embolotherapy, 107-118. Google Scholar

Amrizal, Husni A. Jalil, Eddy Purnama. (2013). Fungsi Pengawasan Dewan Perwakilan Rakyat Kabupaten Terhadap Perizinan Dan Pengendalian Menara Telekomunikasi Di Kabupaten Aceh Besar. 1(1), 24-39. Google Scholar

Anam, Syaiful, \& Anwar, Khairil. (2020). Efektivitas Fungsi Pengawasan Dprd Dalam Pelayanan Publik. $\quad$ Reformasi, https://doi.org/10.33366/rfr.v10i1.1582 Google Scholar

Asiri, La. (2019). Fungsi Dewan Perwakilan Rakyat Daerah Dalam Pengawasan Kebijakan Daerah (Studi Kasus: Kantor DPRD Kabupaten Buton). Kybernan: Jurnal Studi Kepemerintahan, 5(2), 9-17. https://doi.org/10.35326/kybernan.v5i2.367 Google Scholar

Fauzi, H. Ahmad. (2014). Fungsi pengawasan dprd dalam mewujudkan pelaksanaan pemerintahan daerah yang baik. 11(0854), 197-211. Google Scholar

Junfahrizal, Ramadhani Setiawan, Edison. (1967). Fungsi Pengawasan Dewan Perwakilan Rakyat Daerah Dalam Kebijakan Retribusi Perpanjangan Izin Memperkerjakan Tenaga Kerja. Angewandte Chemie International Edition, 6(11), 951-952. Google Scholar

Karim, Aulia Sobri. (2011). Pelaksanaan Fungsi Pengawasan Dewan Perwakilan Rakyat Daerah ( Dprd ) Kota Salatiga Terhadap Kebijakan Walikota Salatiga Tahun 2010 Skripsi. Google Scholar

Nila Trisna, Husni Jalil, Eddy Purnama. (2015). Pertanggungjawaban pengelolaan anggaran di dewan perwakilan rakyat kabupaten aceh barat. 3(1), 76-84. Google Scholar

Peraturan Dewan Perwakilan Rakyat Kabupaten Aceh Barat Nomor 1 Tahun 2021 Tentang Tata Tertib Dewan Perwakilan Rakyat Kabupaten Aceh Barat. (2021). 169. Google Scholar

Perbup Aceh Barat. (n.d.). PERBUP 25 2021_Tunjangan Tranportasi DPRK.pdf. Google Scholar

S.IP., M. I. Desri Irfandi Dr. Dahlan S. H. M. Hu. Mukhrijal. (2020). Analisis Pengawasan Terhadap Pelaksanaan Anggaran Dewan Perwakilan Rakyat Kabupaten Aceh Barat. 5, 1-25. Google Scholar

Trisna, Nila, \& Marefanda, Nodi. (2018). Implementasi Akuntabilitas Terhadap Pengelolaan Anggaran Di Dewan Perwakilan Rakyat Kabupaten Aceh Barat. Jurnal Public Policy, 3(1), 1-12. https://doi.org/10.35308/jpp.v3i1.160 Google Scholar 
Salma, Cut Asmaul Husna

First publication right:

Jurnal Syntax Fusion: Jurnal Nasional Indonesia

This article is licensed under:

(ㅇ) (1) ( $)$ 